\title{
High Fluoride Dentifrices for Elderly and Vulnerable Adults: Does It Work and if So, Then Why?
}

\author{
Kim Rud Ekstrand \\ Department of Odontology, University of Copenhagen, Copenhagen, Denmark
}

\section{Key Words}

Effectiveness $\cdot$ High fluoride dentifrices $\cdot$ Root caries lesion

\begin{abstract}
The primary aim of this work is to present the available evidence that toothpastes containing $>1,500 \mathrm{ppm}$ fluoride $(2,500-2,800$ and 5,000 ppm F) provide an additional caries preventive effect on root caries lesions in elderly patients compared to traditional dentifrices (1,000-1,450 ppm F). The secondary aim of this paper is to discuss why high fluoride dentifrices in general should perform better than traditional F-containing toothpaste. When examining the few studies that have considered the preventive benefits of high fluoride products on root caries the relative risk appears to be around 0.5 , and the risk can thus be halved by exchanging traditional F-containing toothpaste for toothpaste containing 5,000 ppm F. There is reasonable evidence that high fluoride dentifrices significantly increase the fluoride concentration in saliva during the day and the fluoride concentration in plaque compared to traditional $\mathrm{F}$ toothpaste. Furthermore, the use of toothpaste with 5,000 ppm F significantly reduces the amount of plaque accumulated, decreases the number of mutans streptococci and lactobacilli and possibly promotes calcium fluoride deposits to a higher degree than after the use of traditional F-containing toothpaste.

(c) 2016 The Author(s)

Published by S. Karger AG, Basel
\end{abstract}

\section{KARGER}

E-Mail karger@karger.com www.karger.com/cre

\section{(c) 2016 The Author(s) \\ Published by S. Karger AG, Basel 0008-6568/16/0507-0015\$39.50/0}

This article is licensed under the Creative Commons AttributionNonCommercial-NoDerivatives 4.0 International License (CC BYNC-ND) (http://www.karger.com/Services/OpenAccessLicense) Usage and distribution for commercial purposes as well as any distribution of modified material requires written permission.
The effect of topical fluoride on caries is well addressed in the literature. This paper acknowledges that fluoride affects the caries process by reducing demineralization and enhancing remineralization [Fejerskov et al., 1981; Fejerskov, 2004; Twetman and Ekstrand, 2013]. Even with low concentrations of fluoride $(<0.1 \mathrm{ppm})$ in the plaque/saliva interface, it is a supersaturated solution with respect to fluorhydroxyapatite (FHAP) at slightly acidic conditions ( $\mathrm{pH}$ down to 4.0). Thus, when the $\mathrm{pH}$ drops below 5.5, said to be the critical $\mathrm{pH}$ for hydroxyapatite (HAP) and HAP is dissolved, FHAP is at the same time precipitated at the surface of the crystals. When the $\mathrm{pH}$ rises again (above 5.5), both HAP and FHAP are precipitated at the surface [Twetman and Ekstrand, 2013].

Theoretically, fluoride will also influence microbial metabolism by interfering with enolase, an enzyme that is used by bacteria in the fermentation of carbohydrates. However, studies indicate that it requires a high concentration of fluoride (>10 ppm) [Murray et al., 1991], which is rarely achieved in dental plaque [Larsen and Bruun, 1994].

Fluoride is very reactive and will, when it comes into contact with the dental hard tissue or the plaque/saliva, combine with other elements, such as calcium. When the fluoride concentration in the plaque/saliva interface is above $100 \mathrm{ppm}$, calcium fluoride is formed; the higher the

Kim Rud Ekstrand

Section 2, Department of Odontology, University of Copenhagen Nörre Alle 20

DK-2200 Copenhagen N (Denmark)

E-Mail kek@sund.ku.dk 
fluoride concentration, the more calcium fluoride is formed [Bruun and Givskov, 1991, 1993; Larsen and Bruun, 1994].

Thus, the significant impact of topical fluoride on caries control is that fluoride is present at the plaque/saliva interface, while the pre-eruptive (systemic) effect of fluoride, previously praised as the benefit of fluoride in caries prevention [Arnold, 1945], seems to play only a minor role, if any [Thylstrup, 1990]. Furthermore, precipitated calcium fluoride products act as a temporary storage of fluoride from which the active ion is gradually released.

With this in mind, methods of applying fluorides to the oral cavity can be performed at community levels (as fluoridated water, milk or salt) or at individualized levels (characterized by professional or self-care applications) [Twetman and Ekstrand, 2013]. Most used among the self-care methods are fluoridated toothpastes, the uses of which have largely been credited for the decrease in caries seen since the 1960s. According to Lippert [2013], tooth powders or toothpastes are known to have been used by ancient Egyptians. In 1914, the first attempt to add fluoride to toothpaste was made, but it was not until the mid-1950s that fluoride-containing toothpastes were first marketed in the USA. The launch of F-containing toothpastes was based on studies performed during the 1940s-1950s. The first study, however, using $500 \mathrm{ppm}$ sodium fluoride, showed no effect on caries [Bibby, 1945], while another study [Muhler et al., 1954] using 1,000 ppm stannous fluoride showed a significant reduction in caries occurrence in children. With regard to the question of how much fluoride toothpaste can contain, there are different regulations in different countries. In the USA, fluoride compounds are regulated as drugs and the maximum permissible fluoride concentration is between 1,000 (MFP) and 1,100 ppm (NaF and $\mathrm{SnF}$ ), while in the EU fluoride compounds are regulated as cosmetics and the maximum permissible fluoride concentration is $1,500 \mathrm{ppm}$. Higher fluoride concentration products (such as 2,800 and $5,000 \mathrm{ppm}$ ) are available as pharmaceutical products in many countries and require the prescription of a dentist.

The clinical efficacy of fluoride toothpaste $(\leq 1,500$ ppm) has been estimated at approximately $24 \%$ compared to placebo [Marinho et al., 2003; Walsh et al., 2010]. Furthermore, the preventive effect of fluoridated toothpaste was found to increase with higher fluoride concentration in the toothpaste, demonstrating a clear dose-response model up to $2,800 \mathrm{ppm}$. Therefore, it was logical to launch F-containing toothpaste with $>1,500 \mathrm{ppm} \mathrm{F}$. Most recognized high fluoride-containing toothpastes comprise 2,500-2,800 or 5,000 ppm F. Davies and Davies [2008] stated that toothpaste containing 2,500 ppm F re- sulted in an $18 \%$ reduction in caries increment in children compared to toothpaste with $1,000 \mathrm{ppm} \mathrm{F}$.

In many countries, the elderly population is increasing as a proportion of the total population, and these individuals are living longer, often maintaining many of their own teeth. In Denmark, for example, a recent survey showed that only $14 \%$ of vulnerable elderly people in Copenhagen had full dentures [Christensen et al., 2012]. Another national survey showed that those aged 65 and older in Denmark who had natural teeth had an average of 24 teeth, the mean DMFT was 23 and the decay component made up less than 1 tooth of the DMFT index [Kongstad et al., 2013]. However, a further $7 \%$ had 1 or more untreated root caries lesions, while $45 \%$ had 1 or more root surface restorations [Christensen et al., 2015]. A German study from 2006 showed that the prevalence of root caries lesions increased from about $16 \%$ in 1997 to $45 \%$ in 2006 among 65- to 74-year-olds [Michaelis and Schiffner, 2006].

The first aim of this paper is to present the available evidence that toothpaste containing $>1,500 \mathrm{ppm}$ fluoride provides an additional caries-preventive effect compared to traditional F-containing toothpaste. As attention is given to elderly and vulnerable adults, this paper will focus on root caries lesions. This is not to ignore the fact that coronal caries in older adults is an issue - indeed their caries increment on coronal surfaces is similar to that of younger children (1 new carious surface per year). However, the available literature on coronal caries in this group is sparse. The second aim of this paper is to discuss why high fluoride dentifrices in general perform better than traditional F-containing toothpaste.

\section{Statistical Considerations}

A common way to express the outcome of clinical trials is the preventive fraction, which is the difference in mean caries increment between treatment and control groups, expressed as the percentage of mean caries in the control group. Another measurement commonly reported is the risk ratio (RR), which is the risk of the event in the study group divided by the risk of the event in the control group. To calculate the RR, the number of active lesions at the final examination out of the total number of lesions has to be known in the study group as well as in the control group. Data from Ekstrand et al. [2008] are used in this example (table 1 ): $\mathrm{RR}=57 / 130$ divided by $98 / 144=0.65$. Thus, in this study the participants in the study group had a 0.65 lower risk of active root caries lesions compared to the control group.
16

Caries Res 2016;50(suppl 1):15-21 DOI: $10.1159 / 000443021$
Ekstrand 
Table 1. Two-by-two table shows data to exemplify how to calculate the RR

\begin{tabular}{lll}
\hline & Events & Total \\
\hline Study intervention & 57 & 130 \\
Control intervention & 98 & 144 \\
\hline
\end{tabular}

\section{Aims of the Study}

Searching for Studies Examining the Effect of High

Fluoride Dentifrices on Root Caries Lesions and

Results from the Included Papers

In 2015, Wierichs and Meyer-Lueckel [2015] reviewed among other preventive topics the effect of high fluoride concentration toothpaste products on root caries in adults. They performed a thorough search and identified 11 studies from 1947 to 2014 . Of the 11 studies only 2, dealing with 5,000 ppm toothpaste, passed the inclusion criteria. The RR of 1 of the 2 studies, that of Baysan et al. [2001], was 0.85 (95\% Cl, 0.52-0.80). In the other selected study by Ekstrand et al. [2013], the RR was 0.41 (95\% CI, $0.33-0.50)$. When the 2 studies were combined, the total number of lesions in the test and control groups was 315 versus 321, respectively, and the RR was 0.49 (95\% CI, $0.42-0.57)$. The test for overall effect was $\mathrm{p}<0.00001$ and the heterogeneity was $\chi^{2}=9.40$, d.f. $=1(\mathrm{p}=0.002), \mathrm{I}^{2}=$ $89 \%$. The latter values indicate that the studies involved $(\mathrm{n}=2)$ were comparable on essential parameters, e.g. how to assess whether a lesion is arrested or active. However, the risk of bias of the included study was different as the authors of the review assessed the paper by Baysan et al. [2001] to have a lower risk of bias than the paper by Ekstrand et al. [2013].

The present author found 2 other randomized clinical trials that were not included in the review by Wierichs and Meyer-Lueckel [2015]. The trials showed RR $=0.65$ [Ekstrand et al., 2008] (see above) and 0.72 (82/127 divided by 111/124) in the study by Lynch et al. [2000]. The latter study contains the 3-month results of the study of Baysan et al. [2001] already mentioned above. Yet another randomized clinical trial was identified [Srinivasan et al., 2014], but the RR could not be calculated from the study. However, at the end of the study period, ANOVA revealed significantly better surface hardness scores of the lesions in the test groups than in the control groups $(\mathrm{p}<$ 0.0001 ). The study concluded that the application of a high fluoride-containing dentifrice $(5,000 \mathrm{ppm} F)$ in adults twice daily significantly improves the surface hard- ness of otherwise untreated root caries lesions compared to the use of regular fluoride-containing toothpastes.

\section{Discussing Why High Fluoride Dentifrices in General Perform Better than Traditional F-Containing Toothpaste}

Table 2 provides an overview of studies that have examined the relationship between fluoride in toothpaste and the fluoride concentration in saliva, in plaque and changes in the plaque. Of the identified papers, all were clinical trials where the designs were based on examining the difference between outcome variables after using toothpaste with 5,000 ppm F versus that with 1,150-1,450 ppm F. Authors, publication year, aim(s), designs and main results are presented in the summary table.

\section{Discussion}

Studies have revealed that high fluoride toothpaste has a more preventive influence on caries in children, adolescents and young adults than traditional toothpaste with 1,050-1,450 ppm F [Marinho et al., 2003; Davies and Davies, 2008; Wells, 2010]. The first aim of this paper was to look for evidence of high fluoride toothpaste and to assess whether it has a greater potential to prevent caries in the elderly/vulnerable section of the population than traditional toothpaste with 1,050-1,450 ppm F. In the older patient cohort clinical studies have focused on root caries [Michaelis and Schiffner, 2006; Christensen et al., 2015], with no literature identified assessing coronal caries in this group. Root caries is an important clinical entity in the older adult, but coronal and secondary caries continues to be an issue and will require research effort in the future.

Due to the fact that only few randomized clinical trials have been conducted, there is not conclusive evidence at the highest level that high fluoride toothpaste performs better than traditional fluoridate toothpaste in the prevention of root caries. However, data from the few randomized clinical trials in this area indicates at a strong level of evidence that there is a positive influence by using toothpaste with 5,000 ppm F on the prevention or arrest of root caries lesions in the older adult population [Lynch et al., 2000; Baysan et al., 2001], including the elderly frail [Ekstrand et al., 2008] and vulnerable [Ekstrand et al., 2013]. The RR appears to be around 0.5 , and thus the risk can be halved by shifting from using traditional F-containing toothpaste to toothpaste containing 5,000 ppm F. No clinical randomized trials have tested the effect of toothpaste with 2,500-2,800 ppm F on elderly people. 
Table 2. Overview of selected articles which deal with the influence of high fluoride dentifrices on caries-relevant factors compared to traditional fluoride-containing toothpaste

\begin{tabular}{|c|c|c|c|c|}
\hline Authors & Year & Aim & Design & Results \\
\hline $\begin{array}{l}\text { Nordström and } \\
\text { Birkhed }\end{array}$ & 2009 & $\begin{array}{l}\text { Fluoride retention in } \\
\text { proximal plaque and saliva } \\
\text { and the effect of water } \\
\text { rinsing after brushing }\end{array}$ & $\begin{array}{l}\text { Cross-over on } 19 \text { - to } 3 \text { - year-olds } \\
(\mathrm{n}=26)\end{array}$ & $\begin{array}{l}\text { The difference in F concentration per unit weight } \\
\text { of plaque }(\mathrm{n}=16) \text { was } 2.8 \text { times higher }(\mathrm{p}<0.05) \\
\text { after using toothpaste with } 5,000 \mathrm{ppm} \mathrm{F} \text { versus } \\
1,450 \mathrm{ppm} \text { toothpaste }\end{array}$ \\
\hline $\begin{array}{l}\text { Nordström and } \\
\text { Birkhed }\end{array}$ & 2013 & $\begin{array}{l}\text { Effect of a third application } \\
\text { of toothpaste, including a } \\
\text { 'massage' method, on } \\
\text { fluoride retention and } \mathrm{pH} \\
\text { drop in plaque }\end{array}$ & $\begin{array}{l}\text { Cross-over on } 23 \text { - to } 38 \text {-year-olds } \\
(\mathrm{n}=16)\end{array}$ & $\begin{array}{l}\text { Brushing with high fluoride toothpaste } 3 \text { times a } \\
\text { day increased the fluoride concentration in saliva } \\
\text { almost } 4 \text { times compared to standard toothpaste } \\
\text { twice a day. The fluoride retention in plaque } \\
\text { increased significantly as well }\end{array}$ \\
\hline Nordström et al. & 2009 & $\begin{array}{l}\text { Effect on de novo plaque } \\
\text { formation }\end{array}$ & $\begin{array}{l}\text { Cross-over on } 21 \text { - to } 43 \text {-year-olds } \\
(\mathrm{n}=16)\end{array}$ & $\begin{array}{l}\text { Toothpaste slurry containing } 5,000 \mathrm{ppm} \text { fluoride } \\
\text { reduced the formation of new dental plaque on } \\
\text { tooth surfaces }\end{array}$ \\
\hline Lynch et al. & 2000 & $\begin{array}{l}\text { To compare the } \\
\text { effectiveness of Prevident } \\
(5,000 \mathrm{~F}) \text { and Colgate } \\
\text { Winterfresh Gel }(1,100 \\
\text { ppm F) to arrest root caries } \\
\text { lesions }\end{array}$ & $\begin{array}{l}3 \text { months longitudinally on }>18 \text {-year- } \\
\text { olds } \\
(\mathrm{n}=201)\end{array}$ & $\begin{array}{l}\text { Plaque scores were reduced in those using } \\
\text { Prevident } 5,000(\mathrm{p}<0.001)\end{array}$ \\
\hline Mannaa et al. & $2014 a$ & $\begin{array}{l}\text { To measure the effects of a } \\
\text { toothpaste containing } 5,000 \\
\text { ppm F on caries-related } \\
\text { factors in dental plaque and } \\
\text { saliva }\end{array}$ & $\begin{array}{l}6 \text { weeks longitudinally on mothers } \\
\text { with an average age of } 38.4 \text { years } \\
(\mathrm{n}=17) \text { and } 17 \text { teenagers with an } \\
\text { average age of } 14.5 \text { years }(\mathrm{n}=17) \\
\text { Sampling of approximal fluid for } \\
\text { fluoride analysis and approximal } \\
\text { plaque for organic acid analysis was } \\
\text { performed } \\
\text { Counts of cariogenic microorganism } \\
\text { were performed at each of } 4 \text { visits }\end{array}$ & $\begin{array}{l}\text { Six weeks' use of toothpaste containing } 5,000 \mathrm{ppm} \\
\text { F significantly increased the approximal fluid } \mathrm{F} \\
\text { concentration }(\mathrm{p}<0.05) \\
\text { Changes in interproximal plaque acidogenicity } \\
\text { were noted, including significant reductions in } \\
\text { AUC }(5.7 \text { and } 6.2 \text {, respectively) and maximum } \mathrm{pH} \\
\text { fall and an increase in minimum } \mathrm{pH}(\mathrm{p}<0.05) \\
\text { A significant increase in the salivary buffer capacity } \\
\text { and a reduction in the salivary mutans streptococci } \\
\text { were observed ( } \mathrm{p}<0.05)\end{array}$ \\
\hline Mannaa et al. & $2014 b$ & $\begin{array}{l}\text { To assess the caries risk } \\
\text { following } 6 \text { weeks' use of } \\
\text { toothpaste containing 5,000 } \\
\text { ppm F using 'Cariogram' } \\
\text { software }\end{array}$ & $\begin{array}{l}6 \text { weeks longitudinally on } 17 \text { mothers } \\
\text { with an average age of } 38.4 \text { years } \\
(\mathrm{n}=17) \text { and teenagers with an } \\
\text { average age of } 14.5 \text { years }(\mathrm{n}=17) \\
\text { Mutans streptococci and lactobacilli } \\
\text { counts were performed at each of } 4 \\
\text { visits }\end{array}$ & $\begin{array}{l}\text { A statistically significant linear trend was observed } \\
\text { for mutans streptococci counts }(\mathrm{p}<0.01) \text { and the } \\
\text { number of subjects with a salivary concentration of } \\
\text { mutans streptococci }<10^{3} \text { increased at each visit; } \\
\text { the same trend was also observed for lactobacilli } \\
\text { and buffer capacity scores }(\mathrm{p}=0.04 \text { and } \mathrm{p}=0.03 \text {, } \\
\text { respectively) }\end{array}$ \\
\hline
\end{tabular}




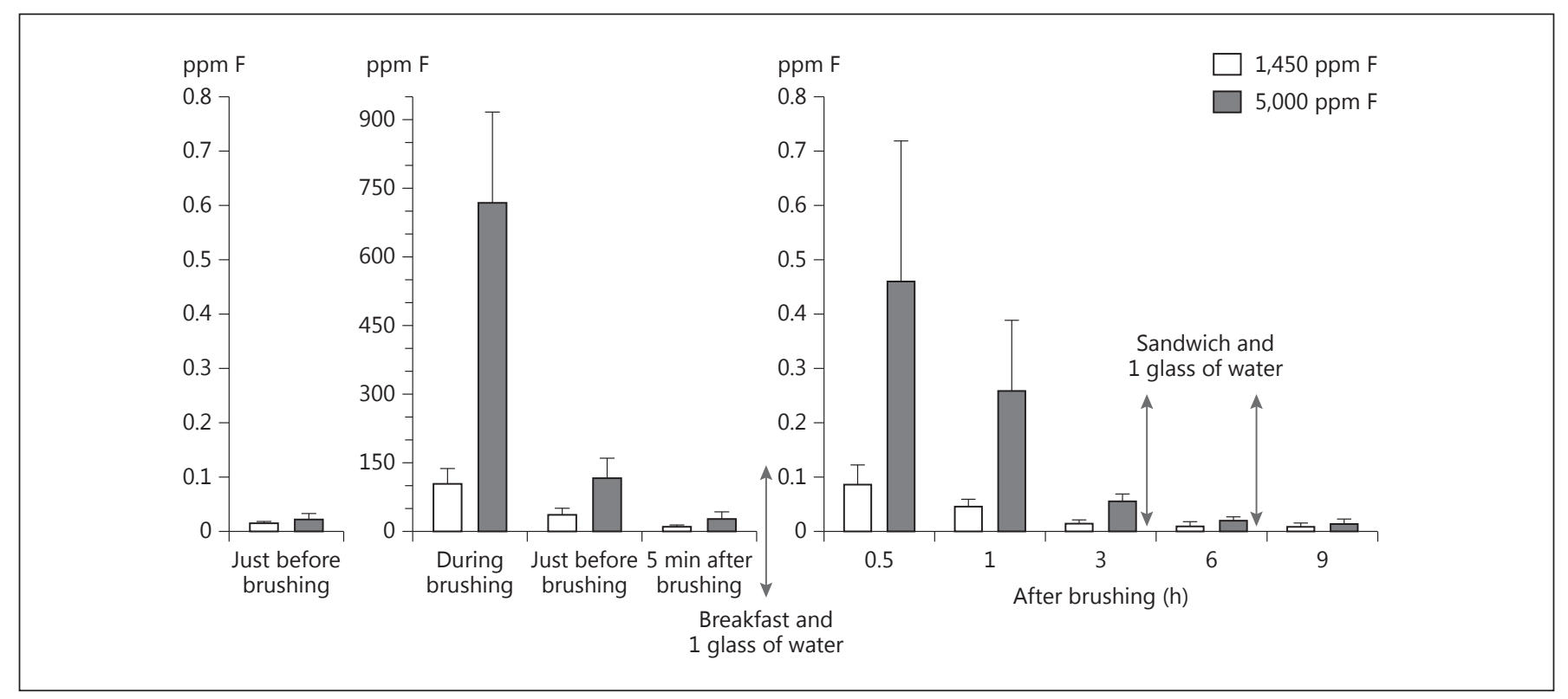

Fig. 1. Fluoride concentrations in whole saliva up to $9 \mathrm{~h}$ after brushing for 2 min with $0.6 \mathrm{~g}$ of toothpaste containing $\mathrm{NaF} 1,450$ ppm F or NaF 5,000 ppm F. The week up to the measurements the participants had brushed twice a day using toothpaste with either
1,450 or 5,000 ppm F, and just before the measuring started there were no significant differences in the $\mathrm{F}$ in saliva whether the participants had used the toothpaste with 1,450 or 5,000 ppm F. Please note that the scale on the y-axis changes.
With this in mind the second aim of this paper was to discuss why high fluoride dentifrices perform better than traditional fluoride dentifrices on both crown and root caries and in all examined age groups. Figure 1 shows the fluoride concentration in saliva in 10 dental students up to $9 \mathrm{~h}$ after tooth brushing using toothpaste with either 1,450 or 5,000 ppm F [Ekstrand, 2006]. The fluoride concentration in saliva was significantly higher after the use of toothpaste with 5,000 ppm compared to $1,450 \mathrm{ppm} \mathrm{F}$ up to $6 \mathrm{~h}$ after tooth brushing. Figure 1 also shows a very high fluoride concentration in saliva during tooth brushing using toothpaste with 5,000 ppm F, at $700 \mathrm{ppm} F$ during tooth brushing and dropping to about $100 \mathrm{ppm} F$ just after brushing. In contrast, using toothpaste with 1,450 ppm $\mathrm{F}$ the concentration was only about $100 \mathrm{ppm} F$ during tooth brushing, dropping to less than 50 ppm just after tooth brushing. Thus, and in accordance with our knowledge about the effect of fluoride on caries [Fejerskov, 2004], the following questions can be asked:

- is the fluoride concentration in the tooth/plaque/saliva interface significantly higher after using high versus traditional F-containing toothpaste?

If so,

- can it influence caries-related factors in the dental plaque and saliva?

Effect of High Fluoride Dentifrices on Root Caries Lesions
- Furthermore, is the fluoride concentration so high after the use of high F-containing toothpaste that it can introduce calcium fluoride products, which can participate in the remineralization process?

As seen from table 2 an increasing fluoride concentration in saliva was also noted by Nordström and Birkhed [2009, 2013] (young adults), Ekstrand et al. [2015] (adults aged 65 years and older) and Mannaa et al. [2014] (teenagers/mothers after use of toothpaste with 5,000 compared to $1,450 \mathrm{ppm} \mathrm{F}$ ). Actually, in the extreme, the data from the study by Ekstrand et al. [2015] showed an average fluoride concentration of around $1 \mathrm{ppm}$ in the saliva during the whole day when 5,000 ppm of fluoridated toothpaste was used 3 times/day $(1 \mathrm{~g})$ and the teeth were smeared with a little drop of the 5,000 ppm toothpaste twice a day. According to the findings by ten Cate and Duijsters [1983] and ten Cate [2013], such values make it quite difficult for caries to develop and progress.

It is stated that if the fluoride concentration in plaque is higher than $10 \mathrm{ppm}$, then an influence on the plaque metabolism can be expected [Murray et al., 1991]. Nordström and Birkhed $[2009,2013]$ showed that the fluoride accumulation in proximal plaque was borderline significantly higher after the use of toothpaste containing 5,000 ppm F than that with 1,450 ppm F (table 2). The fluoride 
concentration in plaque after the use of 5,000 ppm toothpaste reached the level of around $14 \mathrm{ppm} \mathrm{F}$, while the corresponding value after the use of toothpaste with 1,450 ppm $\mathrm{F}$ was around 10 ppm. Mannaa et al. [2014a, b] even found that the $\mathrm{pH}$ dropped less after rinsing with $10 \%$ sucrose solution when tooth brushing was performed using 5,000 ppm toothpaste compared to toothpaste with $1,450 \mathrm{ppm}$ F. Thus, even though the fluoride concentration in plaque does not reach $10 \mathrm{ppm}$ for a longer period, it seems that the higher concentration of fluoride changes the cariogenic potential in the plaque, perhaps by decreasing the number of lactate-forming microorganisms [Mannaa et al. 2014b], which then results in the $\mathrm{pH}$ not dropping so low after a cariogenic rinsing in $10 \%$ sucrose. This may also explain that Lynch et al. [2000], Baysan et al. [2001] and Nordström et al. [2009] found lower plaque scores after the use of 5,000 ppm toothpaste compared to toothpaste with 1,450 ppm F (table 2). Tenuta et al. [2009] even suggested that the $\mathrm{F}$ uptake by dental plaque not removed by brushing may be the main reason of the anticaries effect of dentifrices.

It has been acknowledged that calcium fluoride is formed when the fluoride concentration is higher than 100 ppm F [Larsen and Bruun, 1994; ten Cate, 1997] and that traditional F-containing toothpaste does not create a significant amount of calcium fluoride [Tenuta and Cury, 2013]. To the best knowledge of the author, no studies have investigated the amount of calcium fluoride formed on the teeth after the use of high fluoride toothpaste. As seen in figure 1 the fluoride concentration in saliva reaches about $700 \mathrm{ppm}$ during tooth brushing with toothpaste containing 5,000 ppm F and stays around $100 \mathrm{ppm}$ just after tooth brushing. This indicates that during the period of $2 \mathrm{~min}$ it is possible that calcium fluoride can precipitate, particularly in the accessible root caries lesions.

In summary, the available data from the few clinical trials suggest that high-concentration fluoridated toothpaste provides better caries prevention on root caries lesions in the elderly population than traditional F-containing toothpaste. Similar results are seen with coronal caries in younger populations. The mechanism of action is likely to be enhanced F concentration in both saliva and plaque after the use of high F-containing toothpaste compared to traditional F-containing toothpaste. Theoretically, high fluoride toothpaste should also perform better than traditional F-containing toothpaste in the formation of calcium fluoride products. Initial data suggest that by using high fluoride toothpaste concentrations, about 800 ppm F is noted in the saliva within the period of $2 \mathrm{~min}$ that tooth brushing takes, which is about 7 times higher than the $100 \mathrm{ppm}$ required to create calcium fluoride. However, this particular area requires further research.

\section{Disclosure Statement}

The author has no conflicts of interest to declare.

\section{References}

Arnold FA: A discussion of the possibility of reducing dental caries by increasing fluoride ingestion. J Am Coll Dent 1945;12:61-62.

Baysan A, Lynch E, Ellwood R, Davies R, Petersson L, Borsboom P: Reversal of primary root caries using dentifrices containing 5,000 and 1,100 ppm fluoride. Caries Res 2001;35:4146.

Bibby BG: A test of the effect of fluoride-containing dentifrices on dental caries. J Dent Res 1945;24:297-303.

Bruun C, Givskov H: Formation of $\mathrm{CaF}_{2}$ on sound enamel and caries like lesions after different forms of fluoride application in vitro. Caries Res 1991;25:96-100.

Bruun C, Givskov H: Calcium fluoride formation in enamel from semi- or low-concentrated $\mathrm{F}$ agents in vitro. Caries Res 1993;27:96-99.

Christensen LB, Bardow A, Ekstrand K, Fiehn N, Heitmann B, Qvist V, Twetman S: Root caries, root surface restorations and lifestyle factors in adult Danes. Acta Odontol Scand 2015; 73:467-473
Christensen LB, Hede B, Nielsen E: A cross-sectional study of oral health and oral health-related quality of life among frail elderly persons on admission to a special oral health care programme in Copenhagen City, Denmark. Gerodontology 2012:29;392-400.

Davies RM, Davies GM: High fluoride toothpastes: their potential role in caries prevention programme. Dent Update 2008;35:320323.

Ekstrand KR: Concentrations of fluoride in whole saliva after toothbrushing with 1,450 and 5,000 ppm fluoride toothpaste: a pilot study (abstract). Caries Res 2006;40:304.

Ekstrand KR, Ekstrand ML, Lykkeaa J, Bardow A, Twetman S: Whole saliva fluoride levels and saturation indices in 65+ elderly during use of four different toothpaste regimes. Caries Res 2015;49:489-498.

Ekstrand KR, Martignon S, Holm-Pedersen P: Development and evaluation of two root caries controlling programmes for home-based frail people older than 75 years. Gerodontology 2008;25:67-75.
Ekstrand KR, Poulsen JE, Hede B, Twetman S, Qvist V, Ellwood RP: A randomized clinical trial of the anti-caries efficacy of 5,000 compared to $1,450 \mathrm{ppm}$ fluoridated toothpaste on root caries lesions in elderly disabled nursing home residents. Caries Res 2013;47:391-398.

Fejerskov O: Changing paradigms in concepts on dental caries: consequences for oral health care. Caries Res 2004:38:182-191.

Fejerskov O, Thylstrup A, Larsen MJ: Rational use of fluorides in caries prevention. A concept based on possible cariostatic mechanisms. Acta Odontol Scand 1981;39:241-249.

Kongstad J, Ekstrand K, Qvist V, Christensen LB, Cortsen B, Grønbaek M, Holm-Pedersen P, Holmstrup P, Bardow A, Twetman S, Fiehn NE: Findings from the oral health study of the Danish Health Examination Survey 20072008. Acta Odontol Scand 2013;71:1560-1569.

Larsen MJ, Bruun C: Caries chemistry and fluoride - mechanisms of action; in Thylstrup A, Fejerskov O (eds): Textbook of Clinical Cariology. Copenhagen, Munksgaard, 1994, pp 321-252. 
Lippert F: An introduction to toothpaste - its purpose, history and ingredients. Monogr Oral Sci 2013;23:1-14.

Lynch E, Baysan A, Ellwood R, Davies R, Petersson L, Borsboom P: Effectiveness of two fluoride dentifrices to arrest root carious lesions. Am J Dent 2000;13:218-220.

Mannaa A, Campus G, Carlén A, Lingström P Caries-risk profile variations after short-term use of 5,000 ppm fluoride toothpaste. Acta Odontol Scand 2014a;72:228-234.

Mannaa A, Carlén A, Zaura E, Buijs MJ, Bukhary $S$, Lingström P: Effects of high-fluoride dentifrice $(5,000-\mathrm{ppm})$ on caries-related plaque and salivary variables. Clin Oral Investig 2014b;18:1419-1426.

Marinho VC, Higgins JP, Logan S, Sheiham A: Fluoride mouthrinses for preventing dental caries in children and adolescents. Cochrane Database Syst Rev 2003;3:CD002284.

Michaelis W, Schiffner: The Fourth German Oral Health Study (DMS IV). Cologne, Institute of German Dentists, 2006.

Muhler JC, Radike AV, Nebergall WH, Day HG: The effect of a stannous fluoride-containing dentifrice on caries reduction in children. J Dent Res 1954;33:606-612.

Murray JJ, Rugg-Gunn AJ, Jenkins GN: Modes of action of fluoride in reducing caries; in Murray JJ, Rugg-Gunn AJ, Jenkins GN (eds): Fluorides in Caries Prevention, ed 3. Oxford, Wright, 1991, pp 295-323.
Nordström A, Birkhed D: Fluoride retention in proximal plaque and saliva using two $\mathrm{NaF}$ dentifrices containing 5,000 and 1,450 ppm F with and without water rinsing. Caries Res 2009;43:64-69.

Nordström A, Birkhed D: Effect of a third application of toothpastes $(1,450$ and $5,000 \mathrm{ppm}$ F), including a 'massage' method on fluoride retention and $\mathrm{pH}$ drop in plaque. Acta Odontol Scand 2013;71:50-56.

Nordström A, Mystikos C, Ramberg P, Birkhed $D$ : Effect on de novo plaque formation of rinsing with toothpaste slurries and water solutions with a high fluoride concentration (5,000 ppm). Eur J Oral Sci 2009;117:563567.

Srinivasan M, Schimmel M, Riesen M, Ilgner A, Wicht MJ, Warncke M, Ellwood RP, Nitschke I, Müller F, Noack MJ: High-fluoride toothpaste: a multicenter randomized controlled trial in adults. Community Dent Oral Epidemiol 2014;42:333-340.

ten Cate JM: Review on fluoride, with special emphasis on calcium fluoride mechanisms in caries prevention. Eur J Oral Sci 1997;105: 461-465.

ten Cate JM: Contemporary perspective on the use of fluoride products in caries prevention. Br Dent J 2013;214:161-167. ten Cate JM, Duijsters PP: Influence of fluoride in solution on tooth demineralization. I. Chemical data. Caries Res 1983;17:193-199.

Tenuta LM, Cury JA: Laboratory and human studies to estimate anticaries efficacy of fluoride toothpastes. Monogr Oral Sci 2013;23: 108-124.

Tenuta LM, Zamataro CB, Del Bel Cury AA, Tabchoury CP, Cury JA: Mechanism of fluoride dentifrice effect on enamel demineralization. Caries Res 2009;43:278-285.

Thylstrup A: Clinical evidence of the role of preeruptive fluoride in caries prevention. J Dent Res 1990;69:742-750; discussion 820-823.

Twetman S, Ekstrand KR: Caries management by influencing mineralization; in Meyer-Lueckel H, Paris S, Ekstrand KR (eds): Caries Management - Science and Clinical Practice. Stuttgart, Thieme, 2013, pp 177-190.

Walsh T, Worthington HV, Glenny AM, Appelbe P, Marinho VC, Shi X: Fluoride toothpastes of different concentrations for preventing dental caries in children and adolescents. Cochrane Database Syst Rev 2010;1:CD007868.

Wells WL: Prevention of early childhood caries: the possibilities of fluoride varnish. J Okla Dent Assoc 2010;101:18-19.

Wierichs RJ, Meyer-Lueckel H: Systematic review on noninvasive treatment of root caries Lesions. J Dent Res 2015;94:261-271. 